\title{
DESAIN LAPORAN KEUANGAN DAN PERENCANAAN LABA USAHA PADA INDUSTRI KURSI ROTAN DI DESA DULOLONG BARAT KECAMATAN ALOR BARAT LAUT KABUPATEN ALOR
}

\author{
Zainudin Adang Djaha*
}

Masalah yang dibahas dalam penelitian ini adalah Bagaimana Desain Laporan Keuangan Industri Rotan di desa Dulolong Barat Kecamatan Alor Barat laut kabupaten Alor dan Bagaimana Perencanaan Laba Usaha yang dilakukan oleh Industri Rotan di desa Dulolong Barat Kecamatan Alor Barat Laut Kabupaten Alor. Tujuan penelitian adalah Mendesain Laporan Keuangan Industri Rotan di desa Dulolong Barat Kecamatan Alor Barat laut kabupaten Alor, Melakukan Perencanaan Laba Usaha untuk Industri Rotan di desa Dulolong Barat Kecamatan Alor Barat Laut Kabupaten Alor

Hasil penelitian adalah desain laporan keuangan yang dimulai dari penyusunan neraca saldo, melakukan ayat jurnal penyesuaian, menyusun neraca lajur, mendesain laporan keuangan yang terdiri dari Desain laporan keuangan rugi laba, desain laporan keuangan perubahan modal dan desain laporan keuangan neraca. Selanjutnya dilakukan perhitungan perencanaan laba antara perhitungan perencanaan laba menurut perusahaan dan menurut peneliti. Hasil perhitungan menunjukkan bahwa perhitungan menurut peneliti hanya memperoleh laba sebesar Rp. 5.011.500, perolehan laba ini tidak berdasarkan perhitungan harga pokok produksi sehingga keinginan perolehan laba perusahaan di atas $40 \%$ akan tetapi kenyataannya hanya 2,94\%, sedangkan laba yang diperoleh peneliti berdarkan harapan keuntungan oleh perusahaan sebesar Rp. 14.866.495, perolehan laba ini didasarkan pada perhitungan harga pokok produksi dengan keuntungan yang diharapkan yakni $41 \%$

Perusahaan Sentra Industri Rotan belum melakukan perencanaan usaha dengan benar sehingga keuntungan yang diharapkan belum sesuai dengan harapan. Harapan keuntungan yang ditentukan perusahaan berkisar antara 40\% - 45\%, namun penentuannya tidak berdasarkan perhitungan harga pokok dan hanya berdasarkan perdiksi harga jual, maka keuntungan yang diperoleh perusaan hanya sebesar Rp. 5.011.500 atau 2,94\% .

Disarankan agar Perusahaan Sentra Industri Rotan melakukan perhitungan biaya produksi, harga pokok produksi, harga pokok penjualan ayat jurnal penyesuaian, menyusun neraca lajur, menyusun laporan keuangan yang terdiri dari laporan rugi laba, laporan perubahan modal dan laporan neraca, disarankan agar perusahaan sentra industry rotan menentukan harga jual berdasarkan harga pokok produksi sehingga keuntungan yang diharapkan dapat tercapai sesuai rencana.

Kata Kunci : Laporan Keuangan dan Perencanaan Laba

*) Zainudin Adang Djaha ; Dosen Program Studi Akuntansi Sektor Publik Politeknik Negeri Kupang. 


\section{PENDAHULUAN}

Untuk dapat memberikan solusi yang produktif dan upaya pengembangan usaha kearah yang lebih maju, maka diperlukan adanya suatu penelitian ilmiah untuk mengetahui factor - factor penyebap kurang berkembangnya usaha industri kecil dalam hal ini industry kursi rotan, selanjutnya melakukan desain laporan keuangan dan evaluasi usaha dalam kaitannya dengan perencanaan usaha.atas dasar pertimbangan inilah maka peneliti ingin melakukan penelitian dengan judul Desain laporan keuangan dan perencanaan laba usaha pada industri kursi rotan di desa dulolong barat kecamatan Alor Barat Laut kabupaten Alor

\section{RUMUSAN MASALAH}

1. Bagaimana Desain Laporan Keuangan Industri Rotan di desa Dulolong Barat Kecamatan Alor Barat laut kabupaten Alor

2. Bagaimana Perencanaan Laba Usaha yang dilakukan oleh Industri Rotan di desa Dulolong Barat Kecamatan Alor Barat Laut Kabupaten Alor

\section{TUJUAN DAN MANFAAT PENELITIAN}

1.Tujuan Penelitian

a. Mendesain Laporan Keuangan Industri Rotan di desa Dulolong Barat Kecamatan Alor Barat laut kabupaten Alor

b. Melakukan Perencanaan Laba Usaha untuk Industri Rotan di desa Dulolong Barat Kecamatan Alor Barat Laut Kabupaten Alor

\section{Manfaat Penelitian}

a. Tersedianya model laporan keuangan Industri Rotan sehingga dapat dijadikan sebagai acuan dalam menyusun laporan keuangan setiap akhir periode

b. Tersedianya model perencanaan Laba Usaha bagi Indistri Rotan sehingga dapat dijadikan sebagai dasar dalam melakukan perencanaan Laba pada Periode Selanjutnya

\section{TINJAUAN PUSTAKA}

\section{Laporan Keuangan}

Menurut Simangunsong ( $1995: 74$ ) bahwa Laporan keuangan pada dasarnya adalah hasil dari proses akuntansi yang dapat digunakan sebagai alat untuk berkomunikasi antara pihak-pihak yang berkepentingan dengan data atau aktivitas dari perusahaan tersebut. Pihak-pihak yang berkepentingan terhadap posisi keuangan maupun perkembangan suatu perusahaan yaitu para pemilik perusahaan, manajemen perusahaan, para kreditur, para investor, instansi pemerintah di mana perusahaan tersebut berdomisili, dan pihak- pihak lainnya seperti organisasi buruh dan kelompok masyarakat tertentu termasuk masyarakat akademis.

Bagi manajemen perusahaan, laporan keuangan tersebut merupakan alat untuk mempertanggungjawabkan hasil kerja kepada para pemilik perusahaan atas kepercayaan yang telah diberikan kepadanya. Pertanggungjawaban pimpinan perusahaan itu dituangkan 
dalam bentuk laporan keuangan dengan penyajian secara wajar posisi keuangan dan hasil usaha dalam suatu periode tertentu sesuai dengan prinsip-prinsip akuntansi yang dilaksanakan secara konsisten.

\section{Tujuan Laporan Keuangan}

Tujuan pelaporan keuangan yang disampaikan oleh Indratno ( $2013: 21$ ) antara lain:

a. Informasi untuk pengambilan keputusan oleh pihak-pihak yang berkepentingan.

b. Penaksiran prospek arus kas di masa yang akan datang.

c. Informasi mengenai sumber daya perusahaan dan tuntutan-tuntutan terhadap sumber daya untuk menghadapi persaingan dalam pasar dan perkembangan ilmu pengetahuan dan teknologi.

d. Informasi mengenai prestasi dan keuntungan perusahaan

e. Informasi mengenai bagaimana dana diperoleh dan dipergunakan (alokasi dana).

f. Tujuan-tujuan tambahan seperti informasi yang memuat penjelasan dan interpretasi-interpretasi untuk membantu para pemakai memahami informasi keuangan yang disajikan Dengan kata lain, tujuan laporan keuangan secara umum adalah memberikan informasi tentang posisi keuangan, kinerja serta arus kas perusahaan yang bermanfaat bagi sejumlah besar kalangan pengguna laporan dalam rangka membuat keputusan-keputusan ekonomi serta menunjukkan pertanggungjawaban. Dalam rangka mencapai tujuan tersebut, suatu laporan keuangan menyajikan informasi mengenai perusahaan yang meliputi:Aktiva , Kewajiban, Ekuitas, Pendapatan dan beban termasuk keuntungan dan kerugian,dan Arus kas

\section{Prosedur Penyelesaian Laporan Keuangan \\ Untuk menyusun Laporan}

Keuangan maka dapat dilakukan dengan mengacu pada prosedur penyelesaian Laporan Keuangan Berikut ini :

a. Menyusun Neraca Saldo

b. Membuat Jurnal Penyesuaian

c. Menyusun Neraca Lajur

d. Menyusun Laporan Rugi Laba

e. Menyusun Laporan Perubahan Modal

f. Menusun Neraca

g. Membuat jurnal penutup

h. Menyusun Neraca Saldo awal tahun / setelah penutupan buku

i. Melakukan Analisis Kemampuan Keuangan Usaha 
Gambar 01

Siklus Penyelesaian Laporan Keuangan

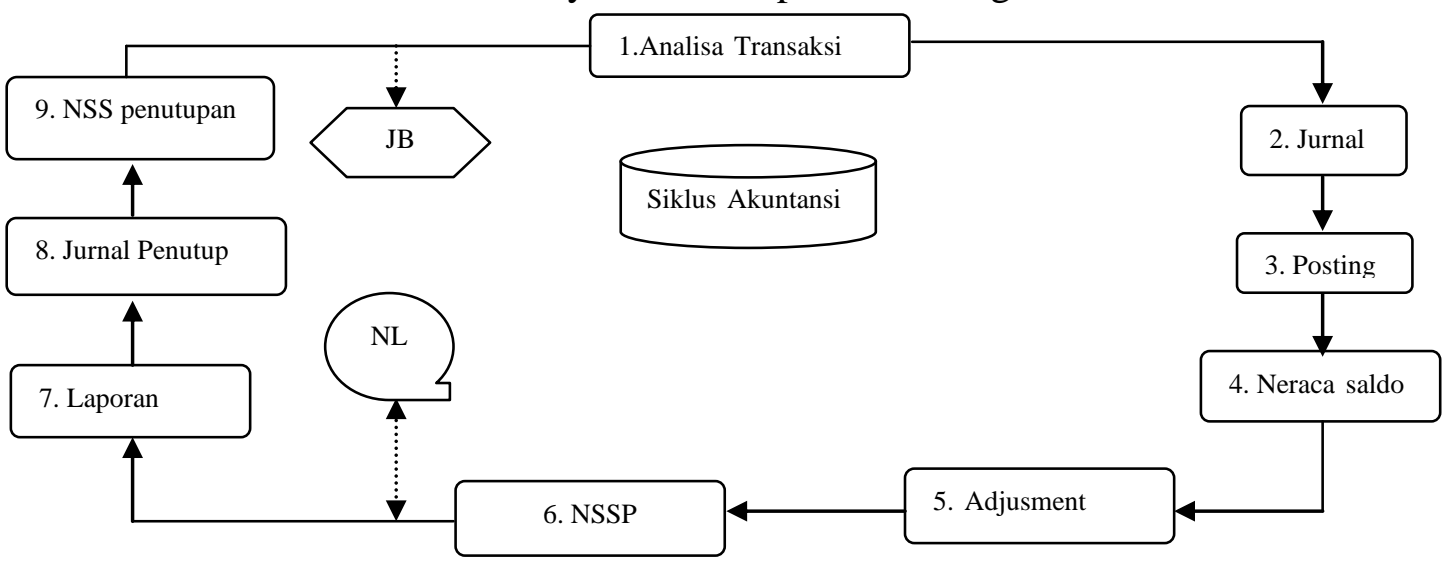

\section{METODE PENELITIAN}

\section{Jenis data;}

1. Data Kualitatif yaitu data yang diperoleh melalui hasil wawancara dengan pimpinan perusahaan sepertu upaya mendapatkan pelanggan, cara mempertahan kan pelanggan, strategi peningkatan produktivitas dan strategi penjualan

2. Data Kuantitatif yaitu data berupa angka - angka seperti data biaya, data penjualan, data piutang, data persediaan, data hutang dan data modal

\section{Sumber data}

Data yang diperlukan dalam penelitian adalah data sekunder adalah data yang telah disiapkan oleh perusahaan seperti data piutang, data jumlah karyawan, data produksi, data penjualan , data persediaan, data biaya, datab aktiva lancer, data aktiva tetap

Teknik pengumpulan Data
1. Teknik Dokumentasi; yakni peneliti mempelajari dokumen dokumen perusahaan yang telah disiapkan

2. Wawancara; yakni peneliti melakukan tanya jawab langsung dengan pimpinan perusahaan untuk memperoleh informasi yang diperlukan dalam analisis penelitian

\section{Teknik Analisis Data}

1. Untuk kepentingan analisis data laporang keuangan dianalisis dengan menggunakan format laporan keuangan dimdaulai dari neraca saldo, penyesuaian, penyusunan neraca lajur, penyusunan laporan biaya produksi, penysunan laporan harga pokok produksi, penyusunan laporan harga pokok penjualan, penyusunan laporan rugi laba penyusunan laporan laba yang ditahan dan laporan neraca 
2. Analisis Perencanaan Laba dilakukan dengan cara harga pokok ditambah dengan Mark-up dimana mark-up di tentukan berdasarkan harga perolehan

\section{ANALISIS HASIL PENELITIAN DAN PEMBAHASAN \\ Desain Biaya Produksi}

Hasil penelitian menunjukkan bahwa biaya bahan baku sebesar Rp. 59.931.000, Biaya tenaga kerja langsung sebesar Rp. 63.000.000, Biaya overhead pabrik sebesar Rp. 5.457.500. Dengan demikian maka total biaya produksi dalam tahun 2014 sebesar Rp. 128.388.500. Untuk lebih jelasnya dapat dilihat dalam tabel berikut ini :

\begin{tabular}{|lr|}
\hline \multicolumn{2}{|c|}{ Industri Rotan } \\
\hline \multicolumn{2}{|c|}{ Laporan Biaya Produksi } \\
\hline Biaya Bahan Baku & $59,931,000$ \\
Biaya Tenaga Kerja Langsung & $63,000,000$ \\
Biaya Overhead Pabrik & $5,457,500$ \\
\cline { 2 - 2 } Jumlah Biaya Produksi & $128,388,500$ \\
\hline
\end{tabular}

Sumber : Centra Industri Rotan Tahun 2015

\section{Desain Harga Pokok Produksi}

Hasil penelitian menunjukkan bahwa persediaan awal bahan baku sebesar Rp. 2.145.000, persediaan bahan baku sebesar Rp. 59.931.000, biaya tenaga kerja langsung sebesar Rp. 63.000.000, biaya overhead pabrik sebesar Rp. 5.475.500, barang yang tersedia untuk dijual sebesar Rp. 130.533.500, selanjutnya persediaan akhir barang dalam proses sebesar Rp. 2.764.000. Dengan demikian maka Harga Pokok Produks yang dikeluarkan dalam tahun 2014 sebesar Rp. 127.761.500. Untuk jelasnya perhitrungan harga pokok produksi dapat dilihat dalam tabel berikut ini :

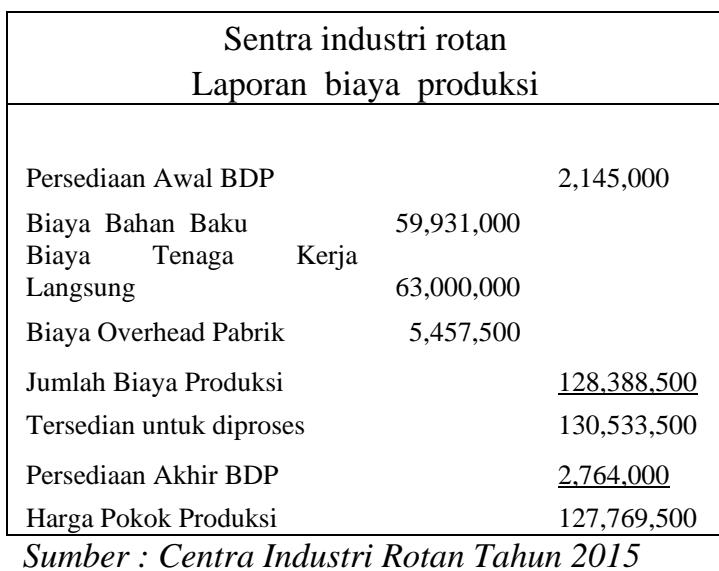

\section{Desain Harga Pokok Penjualan}

Hasil penelitian menunjukkan bahwa Harga Pokok Penjualan yang dikeluarkan oleh sentra industry rotan dalam tahun 2014 adalah sebesar Rp. 129.578.500. Untuk jelasnya dapat dilihat dalam tabel berikut ini :

\begin{tabular}{|lr|}
\hline \multicolumn{2}{|c|}{ Sentra Industri Rotan } \\
\hline \multicolumn{2}{|c|}{ Laporan Harga Pokok Penjualan } \\
\hline \\
Persediaan Barang Jadi Awal \\
Harga Pokok Produksi & $5,684,000$ \\
Jumlah & $127,769,500$ \\
\hline
\end{tabular}

\section{POLITEKNIK NEGERI KUPANG}


\begin{tabular}{|lr}
\hline Persediaan Barang Jadi Akhir & $3,875,000$ \\
Harga Pokok Penjualan & $129,578,500$ \\
\hline Sumber $:$ Centra Industri Rotan Tahun 2015
\end{tabular}

\section{Desain Neraca Saldo}

Hasil penelitian menunjukkan bahwa kas perusahaan sebesar Rp. 3.450.000, piutang usaha sebesar $\mathrm{Rp}$. 8.325.000, perlengkapan kantor sebesar Rp. 4.380.000, barang dalam proses seebesar Rp. 2.764.000, persedaan barang jadi sebesar Rp. 3.875.000, tanah senilai Rp. 36.809.000, bangunan senilai Rp. 54.000.000, akumulasi penyusutan bangunan sebesar Rp. 0, hutang usaha sebesar Rp. 25.450.000, modal usaha sebesar Rp.69.975.505, penjualan sebesar Rp. 180.154.995, harga pokok penjualan sebesar Rp. 129.578.500, biaya gaji pemasaran sebesar Rp. 17.400.000 dan biaya administrasi umum sebesar Rp. 15.000.000. Untuk jelasnya susunan neraca saldo dapat dilihat dalam tabel berikut ini :

\begin{tabular}{|l|r|r|}
\multicolumn{1}{|c|}{} & \multicolumn{2}{|c|}{ Neraca Saldo } \\
\cline { 2 - 3 } Nama Rekening & \multicolumn{2}{|c|}{ Neraca Saldo } \\
\cline { 2 - 3 } & \multicolumn{1}{|c|}{ Debit } & Kredit \\
\hline Kas & $3,450,000$ & \\
Piutang Usaha & $8,325,000$ & \\
Perlengkapan Kantor & $4,380,000$ & \\
Barang dalam Proses & $2,764,000$ & \\
Barang Jadi & $3,875,000$ & \\
Tanah & $36,809,000$ & \\
Bangunan & $54,000,000$ &
\end{tabular}

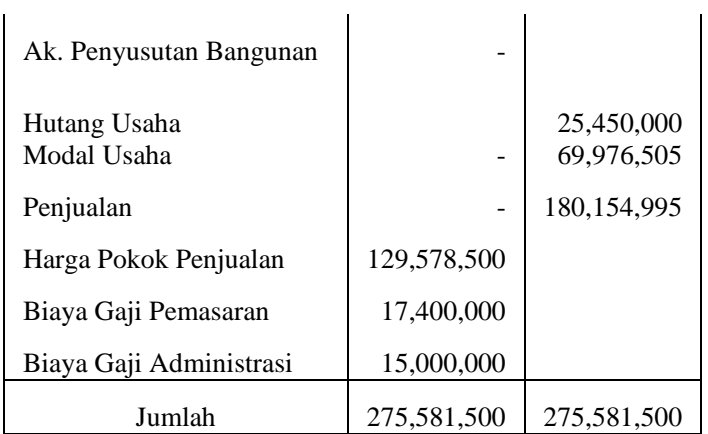

Sumber : Centra Industri Rotan Tahun 2015

\section{Desain Jurnal Penyesuaian}

Model jurnal penyesuaian yang dilakukan ini adala untuk menetukan berapa besar perlengkapan kantor yang telah terpakai menjadi biaya dan berapa jumlah perlengkapan yang masih menjadi aktiva perusahaan. Dari jurnal penyesuaian yang dilakukan di bawah ini menunjukkan bahwa perlengkapan kantor yang telah terbapai atau telah menjadi biaya sebesar Rp. 2.230.000, sehingga jika jumlah ini dikurangkan dengan jumlah perlengkapan kantor di neraca saldo sebesar Rp. 4.380.000, maka perlengkapan yang masih tersisa diakhir tahun adalah sebesar Rp. 2.150.000. Selanjutnya biaya penyusutan bangunan dalam tahun 2014 sebesar Rp. 1.080.000, sehingga nilai buku bangunan sampai dengan tahun 2015 sebesar Rp. $52.950 .000 \quad$ ( 54.000.000 $1.080 .000=52.950 .000$ ). Jurnal pemakaian perlengkapan dan penyusutan dapat dilihat dalam tabel berikut ini : 


\begin{tabular}{|l|l|l|}
\hline \multicolumn{3}{|c|}{ Jurnal Penyesuaian } \\
\hline $\begin{array}{l}\text { Biaya Perlengkapan } \\
\text { Kantor }\end{array}$ & $2,230,000$ & \\
& & $2,230,000$ \\
\hline \multicolumn{3}{|c|}{ Perlengkapan kantor } \\
$\begin{array}{l}\text { Penyusutan Bangunan } \\
\text { Akumulasi Penyusutan } \\
\text { Bangunan }\end{array}$ & $1,080,000$ \\
\hline \multicolumn{2}{|c|}{ Sumber : Centra Industri Rotan Tahun 2015 } \\
\hline
\end{tabular}

\section{Desain Penyusunan Laporan Keuangan \\ Laporan Rugi Laba}

Laporan rugi laba adalah suatu laporan yang menunjukkan pendapatanpendapatan dan biaya-biaya dari suatu unit usaha untuk suatu periode tertentu. Selisih antara pendapatan pendapatan dan biayabiaya merupakan laba yang diperoleh atau rugi yang diderita oleh perusahaan

\begin{tabular}{|c|c|c|}
\hline $\begin{array}{r}\text { Sentra Ind } \\
\text { Laporan } \\
\text { Periode Berakhir }\end{array}$ & $\begin{array}{l}\text { stri Rotan } \\
\text { ugi Laba } \\
1 \text { Desember } 2014\end{array}$ & \\
\hline Penjualan & & $180,154,995$ \\
\hline Harga Pokok Penjualan & & $129,578,500$ \\
\hline $\begin{array}{l}\text { Laba Kotor } \\
\text { Biaya Usaha }\end{array}$ & & $50,576,495$ \\
\hline Biaya Gaji Pemasaran & $17,400,000$ & \\
\hline Biaya Gaji Administrasi & $15,000,000$ & \\
\hline Biaya Pemakaian Perlengkapan Kantor & $2,230,000$ & \\
\hline Penyusutan Bangunan Kantor & $1,080,000$ & \\
\hline Junmlah Biaya & & $35,710,000$ \\
\hline Laba sebelum paak & & $14,866,495$ \\
\hline Pajak penghasilan ps. 21 & $10 \%$ & $1,486,650$ \\
\hline Laba setelah Pajak & & $13,379,846$ \\
\hline
\end{tabular}

Sumber : Centra Industri Rotan Tahun 2015 


\section{Laporan Rugi Perubahan Modal}

Hasil penelitian menunjukkan bahwa arus kas masuk berupa laba tahun bejalan sebesar Rp. 14.866.495. Untuk jelasnya dapat dilihat dalam tabel berikutnini :

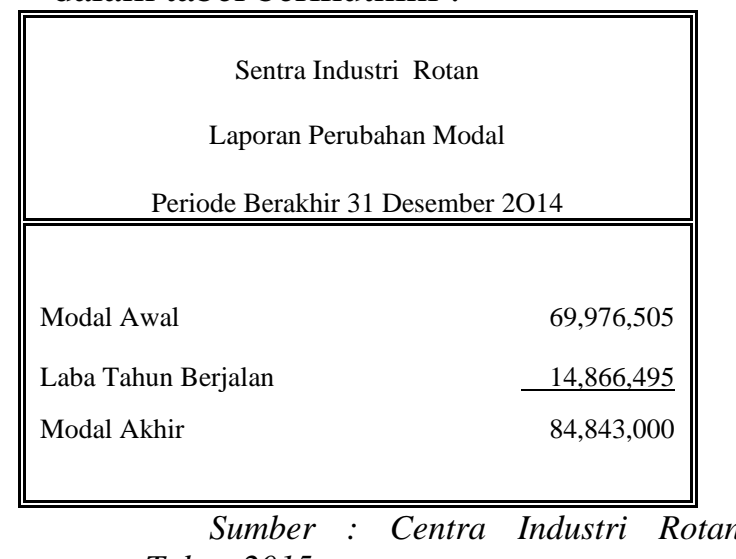

\section{Laporan Neraca}

Hasil penelitian menunjukkan bahwa jumlah aktiva lancar perusahaan sebesar Rp. 20.564.000, jumlah aktiva tetap perusahaan sebesar Rp. 89.729.000 sehingga totak aktiv sebesar Rp. 110,293,000, selanjutnya untuk pasiva, jumlah hutang lancar sebesar $\mathrm{Rp}$. $25,450,000$ dan jumlah modal sebesar Rp. 84,843,000 dengan demikian jumlah pasiva sama dengan jumlah aktiva sebesar Rp.110,293,000. Untuk jelasnya dapat dilihat dalam tabel berikut ini :

Tahun 2015

Sentra Industri Rotan

Neraca

Periode Berakhir 31 Desember 2014

\begin{tabular}{||l|r|l|r||}
\hline \multicolumn{1}{|c|}{ Keterangan } & \multicolumn{1}{c|}{ Jumlah } & Keterangan & \multicolumn{1}{c||}{ Jumlah } \\
\hline \hline Kas & $3,450,000$ & $\begin{array}{l}\text { Hutang } \\
\text { Usaha } \\
\text { Modal }\end{array}$ & $25,450,000$ \\
Piutang Usaha & $8,325,000$ & Usaha & $84,843,000$ \\
Perlengkapan Kantor & $2,150,000$ & & \\
Barang dalam Proses & $2,764,000$ & & \\
Barang Jadi & $\underline{3,875,000}$ & & \\
Jumlah & $20,564,000$ & & \\
Tanah & $36,809,000$ & & \\
Bangunan & & & \\
\hline
\end{tabular}




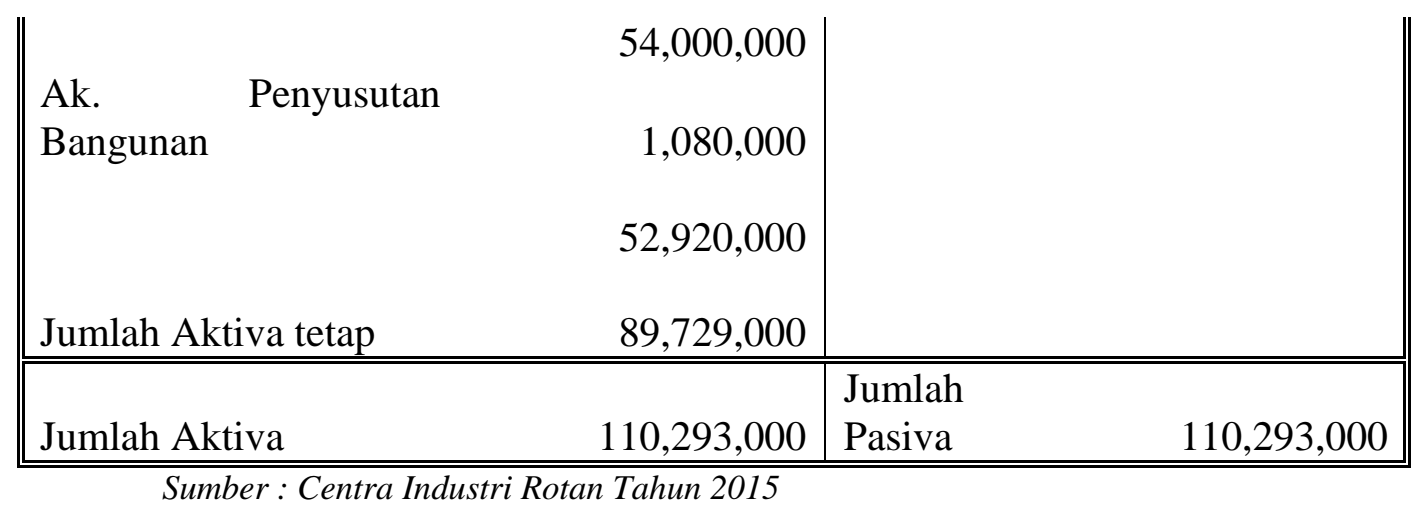

\section{Analisis Perencanaan Laba Usaha}

Hasil penelitian menunjukkan bahwa pihak perusahaan dalam menentukan harga jual kursi rotan per unit tidak berdasarkan prosentase keuntungan tertentu dari harga perolehan atau mark - up, akan tetapi menentukan harga jual berdasarkan predisksi keuntungan, dimana setiap satu unit kursi rotan di jual dengan harga Rp. 250.000. Hasil wawancara peneliti dengan pihak sentra industri menunjukkan bahwa sebenarnya pereka menginginkan keuntungan dari penjualan satu unit kursi berkisar antara $40 \%$ - $45 \%$. Selain itu perusahaan juga belum melakukan perhitungan harga pokok produksi sehingga belum mengetahui besarnya harga pokok produksi yang dikeluarkan dalam setiap tahunnya termasukjuga belum mengetahui harga pokok per unti produksi kursi rotan yang dihasilkan

Dengan kondisi seperti ini, maka berdasarkan hasil wawancaea dan strudi dokumen terhadap catatan dan dokumen keuangan, maka selanjutnya dilakukan perhitungan harga pokok produksi. Hasil perhitungan menunjukkan bahwa perusahaan dalam tahun 2014 telah menghasilkan kursi rotan sebanyak 655 unit dengan total hatga pokok produksi yang dikeluarkan sebesar Rp. 127.769.500, sehingga harga pokok per unit dihitung sebesar Rp. 195.000 ( $127.769 .500 / 655=$ 195.000 ). Dengan demikian maka penulis dapat melakukan perhitungan keuntungan menurut perusahaan dan menurut peneliti sebagai berikut :

\section{Perhitungan keuntungan menurut perusahaan}

Penjualan Rp. 260.000 x 655 unit

Harga Pokok Penjualan

$\underline{129.578 .500-}$

Laba Kotor Penjualan

Biaya usaha :

Biaya Pemasaran

Biaya Gaji Administrasi
$=$ Rp. 170.300 .000

$=\mathrm{Rp}$.

$$
=\text { Rp. } \quad 40.721 .500
$$

Rp. 17.400 .000

Rp. 15.000 .000

\section{POLITEKNIK NEGERI KUPANG}


Biaya Pemakaian Perlengkapan kantor

Biaya Penyusutan Bangunan Kantor

Jumlah Biaya Usaha

Laba bersih

\author{
Rp. 2.230 .000 \\ Rp. $1.080 .000+$ \\ $=$ Rp. 35.710 .000 \\ $=$ Rp. 5.011 .500
}

Hasil perhitungan keuntungan menurut perusahaan berdasarkan prediksi keuntungan antara 40\% - 45\% menghasilkan keuntungan Laba kotor sebesar Rp. 40.721.500 sedangkan laba bersih yang diperoleh sebesar Rp. 5.011.500

\section{Perhitungan keuntungan menurut Peneliti}

Penjualan Rp. 274.950 x 655 unit

Harga Pokok Penjualan

Laba Kotor Penjualan

$$
\begin{aligned}
& =\text { Rp. } 180.154 .955 \\
& =\text { Rp. } 129.578 .500- \\
& =\text { Rp. } 50.576 .495
\end{aligned}
$$

\section{Biaya usaha :}

Biaya Pemasaran

Biaya Gaji Administrasi

Biaya Pemakaian Perlengkapan kantor

Biaya Penyusutan Bangunan Kantor

Jumlah Biaya Usaha

Laba bersih
Rp. 17.400 .000

Rp. 15.000 .000

Rp. 2.230 .000

Rp. $1.080 .000+$

$=\mathrm{Rp} . \quad 35.710 .000$

$=$ Rp. 14.866 .495

Hasil perhitungan keuntungan menurut peneliti berdasarkan prediksi keuntungan antara 40\% - 45\% menghasilkan keuntungan Laba kotor sebesar Rp. 50.576.495 sedangkan laba bersih yang diperoleh sebesar Rp. 14.866.495. penelti menggunakan mark-up atau prosentase laba yang diinginkan oleh pihar perusahaan yakni $41 \%$ dari harga pokok produk per unit dalam menentukan harga jual per unit sebagaimana perhitungan berikut ini :

Harga Pokok Per unit

Mark-up $\quad 41 \% \quad$ x Rp. 195.000

Harga Jual kursi rotan perunit

Harga jual keseluruhan adalah 655 unit x Rp. $274.950=$ Rp. 180.154.955

Hasil perhitungan di atas

menunjukkan bahwa perusahaan memang memprediksi keuntungan antara $40 \%$ - 45\%, akan tetapi dalam menentuan harga jualnya tidak berdasarkan perhitungan
$=$ Rp. 195.000

=Rp. $79.950+$ $=$ Rp. 274.950 harga pokok produksi sehingga kenyataan keuntungan yang diperoleh tidak sesuai dengan harapan yakni hanya memperoleh Rp. 5.011.500 atau keuntungan rill yang diperoleh hanya mencapai 
$2,94 \%$, sedangkan menurut penulis penentuan harga jual ditentukan berdasarkan prediksi keuntungan perusahaan dengan menentukan prosentasi diantara $40 \%-45 \%$ yakni mark-up $41 \%$, maka keuntungan perusahaan dalam Keuntungan menurut peneliti Keuntungan menurut perusahaan Selisih keuntungan

Berdasarkan perhitungan selisih keuntungan di atas, maka dapat diketahui bahwa sebenarnya perusahaan telah membuang keuntungan dalam tahun 2014 PENUTUP sebesar Rp. 8.45.995

Kesimpulan

1. Perusahaan Industri Rotan belum menghitung biaya produksi, harga pokok produksi, harga pokok penjualan, penyusunan neraca saldo, ayat jurnal penyesuaian, menyusun neraca lajur, menyusun laporan keuangan yang terdiri dari laporan rugi laba, laporan perubahan modal dan laporan neraca

2. Perusahaan Industri Rotan belum melakukan perencanaan usaha dengan benar sehingga keuntungan yang diharapkan belum sesuai dengan harapan. Harapan keuntungan yang ditentukan perusahaan berkisar antara $40 \%$ - 45\%, namun penentuannya tidak berdasarkan perhitungan harga pokok dan hanya berdasarkan perdiksi harga jual, maka keuntungan yang diperoleh perusaan hanya sebesar Rp. 5.011.500 atau 2,94\%. tahun 2014 diperoleh sebesar Rp. 14.866.495. Dengan demikian maka penulis dapat melakukan perhitungan selisih keuntungan antara perhitungan menurut penuli dengan perhitungan menurut perusahaan sebagai berikut :

$=$ Rp. 14.866.495

$=$ Rp. $5.011 .500-$

=Rp. 8.945.995

$\mathrm{S}$ a r a n

1. Disarankan agar Perusahaan Industri Rotan melakukan perhitungan biaya produksi, harga pokok produksi, harga pokok penjualan ayat jurnal penyesuaian, menyusun neraca lajur, menyusun laporan keuangan yang terdiri dari laporan rugi laba, laporan perubahan modal dan laporan neraca

2. Disarankan agar perusahaan industry rotan menentukan harga jual berdasarkan harga pokok produksi sehingga keuntungan yang diharapkan dapat tercapai sesuai rencana.

DAFTAR PUSTAKA

Agnes Sawir, 2005, "Analisis Kinerja Keuangan dan Perencanaan Keuangan Perusahaan, Cetakan Kelima ", Jakarta: PT Gramedia Pustaka Utama.

Baridwan, Zaki. Intermediate Accounting, Edisi 8, Penerbit BPFE, Yogyakarta, 2004.

Ely Suhayati dan Sri Dewi Anggadini, 2006, "Pengantar Akuntansi 1", Bandung: Universitas Komputer Indonesia. 
Harahap, Sofyan Safri. Akuntansi Aktiva Tetap, Penerbit PT. Raja Grafindo Persada, Jakarta, 2002.

Helfert, Erich A. 1997. Teknik analisis keuangan : petunjuk praktis untuk mengelola \& mengaturkinerja perusahaan, edisi kesembilan. Jakarta : Erlangga.

Jumingan, 2006, "Analisis Laporan
Keuangan,

Cetakan

Pertama", Jakarta: PT Bumi Aksara.

Albertus, 2013 Prinsip - Prinsip Dasar Akuntansi untuk pemula dan Orang Awam. Balai Penerbit Dunia Cerdas Jakarta

Supriyono 1999, Akuntansi Biaya Pengumpulan Biaya dan Penentuan Harga Pokok. Balai Penerbit FE. UGM Yogyakarta 